\title{
Study of the Tourism Talents Training Mode Focusing on Practical Abilities Liu Ying
}

Dalian Vocational \& Technical College, , 116035,

Keywords: tourism major practical teaching talents training

\begin{abstract}
The rapid development of China's tourism industry stimulates the society's demand on professional applied talents in tourism, especially in the direction of professional tourism planning and management. The boost of the demand for applied tourism talents brings not only the expansion of tourism education but also a series of problems exist in talents training mode. Aimed at the problems of backward practical teaching contents in the teaching process, unstable teaching practical base and the failing in carrying out the teaching practice, this essay promotes the improvement strategies of tourism talents training mode focusing on practical abilities. The strategies include a further definition on the practical teaching target of the tourism major, an enlarged proportion of practical curriculum, an innovated cooperation mode between schools and enterprises to better adapt graduates to the society's demands and a reasonable enlarged teaching staff in practical teaching with managers in enterprises as the guest lecturers.
\end{abstract}

\section{The status quo of the development and demand for talents of China's tourism industry}

China's tourism industry has been developing rapidly for years since the reform and opening (shown in Fig.1) and the domestic tourism income and inbound tourism income has an accelerating growing speed in this century.

China's domestic tourism income increased by $827 \%$ in 13 years as it grew from 317.5 billion yuan in 2000 to over 2.6276 trillion yuan in 2013, approximately this year's gross domestic product of Thailand, which is the tourist attraction of Asia. The inbound tourism income at the same time increased by 318\% with it grew from 16.2 billion dollars in 2000 to 51.664 billion dollars in 2013, approximately the gross domestic product of Bulgaria, which is the country of rose in Europe.

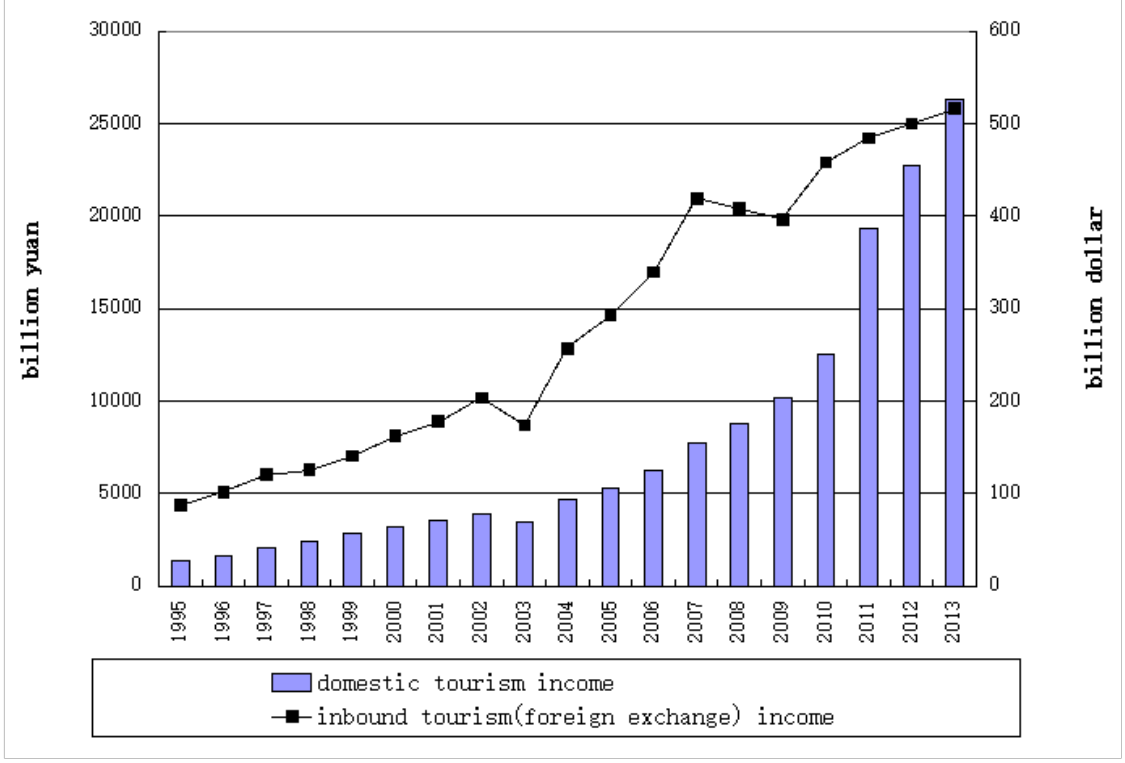

Fig.1 Domestic tourism income

With the rapid development of China's tourism industry, there is a greater demand for professional applied talents of the tourism market. What we can see from the data is that China's tourism industry needs approximately 8 million professionals while there is a shortage of more than 2 million. Institutions, especially travel agencies, hotels and online travel services etc, have a serious demand for high quality professionals. 
The recovery of the major of tourism in China began thirty years ago; it developed and expanded rapidly in this short time, however, it failed to accumulate enough teaching resources and teaching strength. The entering into the big-scale development period of China's professional education of tourism thus brought a series of problems in talents training mode in enlarging the professional education scale.

Therefore, the priority of increasing the employment rate and adapting to regional economic development and social demand is to cultivate practical talents with high abilities by exploring the training method of applied tourism talents according to the actual demand of the tourism market.

\section{The applied talents cultivating mode of tourism and existed problems}

After the development in these years, China's tourism major has formed relatively obvious talents training modes which can mainly be concluded into compound and practical ones. The compound talent training mode emphasizes the comprehensiveness in the cultivation of tourism professionals and its major target is to develop talents that can not only meet the developing demands of society but also carry out intensive theory research. In this mode, professional books and generalized textbooks are used to compound and combine the professional foundation knowledge, theoretical knowledge and relevant professional knowledge and skills. It is those key universities, especially those entailed in Project 211 and Project 985 that applying this compound mode.

The practical training mode emphasizes the practicality of tourism professionals since its major goal is to cultivate talents with high working abilities. Focusing on cultivating practical talents adapting to employment, this training mode usually have its major routes of specialty education, order education and directional training. The training contents, closely related with the teaching target, are mainly practical courses emphasizing the cultivation of practical abilities. The educational bodies applying practical talents training mode are mainly vocational and specialized higher education institutions.

The survey on employment demand revealed that China has a greater demand for practical abilities. According to the official announcement of the Ministry of Education, there is going to be a transformation among universities and colleges. There are 600 colleges and universities, almost the half of the total 1200 national common higher education institutions, that going to transform into vocational education to cultivate skilled talents.

However, the structural disparity between China's talents training and the labor market demand is becoming even more obvious. There are problems exiting in the applied talents training:

The first problem is that practical teaching contents are out of date. According to the induction analysis on the curriculum setting of the tourism major in China's schools and the statistics of word frequency of the course titles (shown in Table.1), theoretical courses of management and economy occupying over a half of the teaching time or class hour stand the top of the list.

Survey on the professional textbook in tourism major reveals that schools with teaching contents of international level accounts for a relatively small proportion as most colleges prefer more conservative ones. The practical teaching managements of most schools are extensive as arranging students only to low-end jobs such as servicers and receptionists in enterprises and public institutions.

The practical teaching contents can barely meet the vocational demand, and this great difference between practice contents and the future vocation leads to the backward of the practical teaching contents of China's tourism major, far behind meeting the demands of talents training.

The second is that the teaching practice bases are unstable. China's enterprises and public institutions were influenced to varying degrees by the exploration of financial crisis and subprime crisis resulted in the unstableness of the teaching bases in tourism education and thus affecting the talents cultivation. 
Table 1: setting of the tourism major

\begin{tabular}{lc}
\hline Course type & Statistical results \\
\hline Economics & 68 \\
management & 141 \\
guide & 30 \\
convention and exhibition & 11 \\
tourism & 44 \\
marketing & 36 \\
geography & 29 \\
culture & 21 \\
service & 23 \\
language & 36 \\
accounting & 47 \\
planning and designing & 37 \\
information system technology & 31 \\
politics and regulations & 44 \\
psychology & 30 \\
ecological environment & 13 \\
\hline
\end{tabular}

Practical courses are the major part of talents cultivation. Some schools, to strengthen the effects of practical teaching, establish practice bases by cooperating with enterprises. Listed practice bases include hotels, travel agencies and online travel service websites etc. There is an exploration of college practice bases in recent years while the teaching effects are actually decreasing.

Researches on the teaching practice bases in three northeast provinces reveal a decreasing tendency of their teaching efficiency mainly caused by the unstableness. Moreover, this unstableness is becoming more serious with the integrating and reconstructing of tourism industry which will certainly influence the practical teaching effects of the practical professional in tourism.

The third problem is the misplacement of teaching practice. While most schools dedicate to the cultivation of practical talents of employment guided by combining the specialty educating, specialty order training and directional training, it is difficult for the implement of practical teaching. Due to the decreased stableness of practical teaching bases, practical teaching is easily formalized. For those schools with unified management in practical teaching, it is difficult to have enough teachers selecting practice units with enough energy.

To implement unified management, most schools would arrange students to travel agencies or hotels to complete practical courses. Students, however, with little working experiences, can rarely complete corresponding work assignments independently and they are therefore often busy with low-end works. For example, when students are arranged to travel agencies or hotels to have practical teaching, they often work as guides or waiters rather than designing tour routes or operating tours in travel agencies or doing room management in hotels.

From the above, there are problems of out-of-date teaching contents, unstable teaching practice bases and misplacement of teaching practice implement exiting during the professional teaching process of China's tourism. It is necessary to change the teaching mode and to strengthen the professional tourism practical teaching effects helping graduates equip with relatively higher employment applicability as well as working abilities.

\section{Research on the improvement of tourism professional training mode}

China's tourism, which has almost completed its internal integration and combination, has its business innovation revolving around tourism product innovation, especially on the tourism product varieties, types and values innovation. Besides, China's tourism industry is now closely connected with modern service industry. Therefore, the professional training of China's tourism should center 
on the practical abilities to cultivate more practical talents qualified for industry innovation.

Here are the improving strategies:

First is to further definite the target of professional tourism teaching. China's tourism majors should identify the running principle of schools of turning to the market needs cultivating new practical talents and giving up the pursuit of comprehensive talents.

Schools should make detailed analysis on the talent needs of the labor market according to their own running and plans on talent training scales to further definite the cultivating orientation and direction of tourism professionals in this period. This can help avoid the problems of ambiguity in school running orientation and assimilation of talents cultivation and to solve the structural disparity in labor supply fundamentally.

Schools can subdivide the tourism major into chain hotel management, foreign hotel management, tourism management, tourism service management, guide, scenic spot planning and scenic spot management according to the job range to cultivate applied tourism professionals. Classes in different directions can be assembled and different running principles can be identified.

Relevant practical teaching bases can then be established to improve the quality of the cultivated talents promoting the school running specialization and teaching characteristics.

Second is to improve the proportion of practical courses. On the basis of a clear professional running orientation, schools should improve the proportion of practice and training courses and construct a talent training mode that focused on practical abilities in combining course learning, in-class practice, base training, course learning and internship. Improving the practical learning time, it successfully transforms the former boring book learning method.

When strengthening practical courses, schools should at the same time combine the professional tourism learning with practical courses in practice bases to help students better understand and master the skills and applications in real life and actual work and thus get the ability mastering theoretical knowledge in an atmosphere similar to their future work. This would shorten the gap between the graduates' knowledge structure and the enterprises' requirements.

Textbooks of the practical teaching in tourism should select materials related with the practical courses and avoid copying the teaching contents from other colleges. Colleges should add or subtract their teaching contents according to their regional labour market demands, tourist cities for instance, should add scenic spot management and tourist route designing to their teaching contents, schools located in the gathering place of tourism websites should then add tourism service management and tourism website management to their practical teaching contents.

The arrangement of the college practical courses should pay attention to the demands of local enterprises and public institutions to cultivate tourism professional better suiting the social demands.

The third is to innovate the cultivating method of school-enterprise cooperation. The innovation of college talents training mode should strengthen the applicable and practicable ability developing in constructing a cooperation method between schools and enterprises in teaching and talents training.

At present, many schools have applied this school-enterprise cooperation training method. However, they are relatively conservative as they mainly sent students to practical bases with enterprises in charge of teaching contents. There is, however, a large variable space in the determination of teaching staff and training method, and the casual training contents often alternate with the change of executives.

It is therefore suggested that schools and enterprises establish a long-time cooperation alliance rather than the former single college-dominance cooperation. Dealing the cooperation mode between schools and enterprises flexibly and encouraging enterprises and public institutions engaging in the talents training plans would take the enterprises participating in the order teaching or directional teaching.

Taking part in the various parts from the determination of training contents to the establishing of teaching staff is also encouraged to construct a real interactive school-enterprise cooperation mode to provide qualified graduates for the society as well as enterprises and public institutions. 
The last one is to enlarge the practical teaching staff reasonably. In the current school-enterprise cooperation, the teaching staff is constructed mainly by teachers with mangers in enterprises and public institutions or training instructors as the supplement. Due to the passive engagement in teaching, the participation of the enterprises' personnel fails to change the teaching method fundamentally, not to mention any big improvement in talent training mode.

It is therefore suggested that in the school-enterprise cooperation, schools should pay attention to the outstanding young and mid-aged managers and training lecturers, who can be taken into the teaching staff by establishing long-time external relationship.

The first step of this procedure is to select young managers and trainee lecturers with good communication skills as guest lecturers, then excellent trainee lecturers can be picked out after a two-or-three-year internship adding to the external teaching staff.

Not only in practical teaching can these high qualified employees be employed by schools as education instructors, but also can direct students at the beginning of their college life their career planning and help them construct their knowledge structure and strengthen their practical working abilities.

The enlargement of practical teaching staff, the critical point of school-enterprise cooperation, would greatly enhance the strength of college tourism teaching.

\section{Conclusion}

Practical talents are the hope and impetus of China's future tourism development. Schools should improve the present talent training mode and create characteristic education defining the professional running orientation.

Treating the improvement of the practical teaching proportion and the enlargement of the number of practical teachers as the starting point in education reform, schools should continuously perfect present tourism professional practical teaching to provide more high qualified talents for the society, enterprises and publics institutions.

\section{References}

[1] SueBecton, BrianGraetz. Small Business- Small Minded? Training Attitudes and Needs of theTourism and Hospitality Industry[J]. Int. J. Tourism Res. . 2001 (2)

[2] Terry Lam,Honggen Xiao. Challenges and Constraints of Hospitality and Tourism Education in China[J]. International Journal of Contemporary Hospitality Management . 2000 (5)

[3] Sobiechowska Paula, Maisch Maire. Work-Based Learning: In Search of an Effective Model. Educational Action Reserch . 2006

[4] Mavis G Sanders, Joyce L. Epstein. School-Family-Community Partnerships and Educational Change: International Perspectives, Extending Educational Change. 2007

[5] Dimitrios Stergiou. Making Sense of Tourism Teaching [J]. Annals of Tourism Research . 2008 (3) 